\title{
OBITUARY
}

\section{Arthur Cyril Hudson}

Mr. A. C. Hudson died on May 12, 1962, in his 87th year when few of his contemporaries (who included Coats and Parsons) survive. Though comparatively little known outside his country or indeed his own teaching hospital, he was a man remarkable both for his professional merit and for his unusual personal qualities.

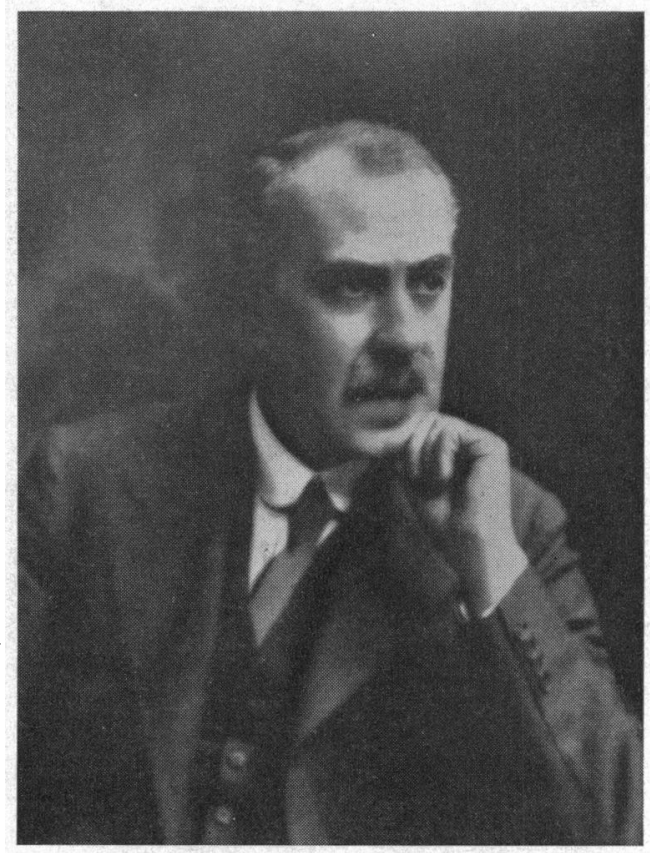

Arthur Cyril Hudson, the youngest son of the vicar of Bingley, Yorkshire, was born on November 30, 1875. He was educated at Rugby and Trinity College, Cambridge, where in addition to taking an honours degree he played tennis for the University and it is said would have gained a rugger blue had he been of heavier physique. He entered St. Thomas's Hospital Medical School in 1899, having won the University Scholarship and qualified M.B., B.Chir. (Cantab.) in 1902; proceeding to M.D. in 1906 and F.R.C.S. (England) in 1905. He held general surgical as well as ophthalmic apppointments at St. Thomas's before becoming House Surgeon at The Royal London Ophthalmic (Moorfields) Hospital where he was able to obtain unrivalled clinical and operative experience. His talents led to his appointment as Curator, then the recognized stepping stone to the staff, and during his tenure of this post he gained extensive experience of ocular pathology which was the basis of his sound judgment of eye diseases. During these early years he not only produced several careful and valuable publications but was largely responsible for improving aseptic methods in the operating theatres and greatly reduced the infectivity rate which resulted from eye operations in the early years of the century.

In 1913 he was appointed Honorary Surgeon to Moorfields and on the retirement of 575 
J. B. Lawford in 1915 joined Herbert Fisher at St. Thomas's Hospital, taking charge of the eye department in 1924 with P. G. Doyne as his junior. He resigned from Moorfields at the early age of 53 , partly to make way for a younger man, but continued at his undergraduate hospital until he reached retiring age in 1935. He was Vice-President of the Ophthalmological Society of the United Kingdom and in 1932-33, as president of the Ophthalmological Section of The Royal Society of Medicine, delivered the presidential address on cataract surgery.

Hudson's work was meticulous and took no àccount of time. His careful examinations coupled with his knowledge of pathology established him as an outstanding clinician who seemed almost to live within the eye. To other London ophthalmic surgeons he was the first choice for second opinions on difficult problems and if he had a fault it was in persisting for too long in trying to improve a hopeless case. As an operator he was without doubt in the front rank, especially in cataract surgery, for he was an artist with the von Graefe knife. As a lecturer he was not very easy to follow because his voice did not carry and because he never used any form of illustration, though what he said was invariably sound if rather above the heads of some of his audience. To his post-graduate students he was the best teacher of his day because of the thoroughness of his examinations with the simple apparatus then available and his willingness to discuss problems fully. At one period no less than a quarter of the ophthalmic surgeons on the staff of London's 'teaching hospitals had been his House Surgeon at St. Thomas's, which is proof of the stimulus of his example and his influence on British ophthalmology. His publications were moderate in number but always carefully compiled and worthy of close attention, and his last paper on a stereoscope of his own design was published in his 80th year. "Hudson's line" perpetuates his name in ophthalmology.

An account of Hudson as an ophthalmic surgeon would be only half the portrait of the man, for his personality was equally remarkable. He was a true Edwardian and a relic of the days of the hansom cab, gaslight, and the golden sovereign, and he went through life without a wife, a secretary, or a motor car. As a bachelor he had plenty of time for reading and was a most excellent conversationalist, for he had acquired knowledge of almost every subject and was especially strong on furniture, works of art, natural history, and salmon fishing. He filled his large house with antiques and became an authority on Persian rugs. All his reports were written personally in long hand and in his letters there was seldom a word without object and nothing was altered or erased. In London he always travelled by cab and his only other journeys were by rail to Scotland for he never went abroad.

Throughout his life, Huddie, as he was nearly always called, retained his interest in sports. He attended the Olympic Games in London after the war and he always kept in touch with the sporting and athletic activities of St. Thomas's Hospital, being for many years president of the Lawn Tennis Club. He presented to the Medical School a tennis court and two squash courts which bear his name and chose several of his friends from among young athletes. His hobby was fly fishing for salmon and his annual holidays were spent on the river Oykell where he was a delightful and generous host.

Hudson's personality was remarkable and he indeed became a legend in his lifetime for though in his work he had both feet on the ground he often had his head in the clouds. He was intelligent and generous, eccentric and absent-minded, but above all he was admired and beloved by his patients and by the men and women who worked with him. Anyone of his era who did not have the good fortune to know him has missed something worth having in life. 